\title{
Russia in Economic Globalization
}

\author{
Valery Smirnov*, Vladislav Semenov, Anna Zakharova, Anzhelika Abramova, Elena \\ Perfilova
}

Chuvash State University, 428015, Chuvash Republic, Cheboksary, Moskovsky prospect, 15, Russia

\begin{abstract}
The article analyzes the current state of the Russian economy in the context of globalization. The research reveals the dominant role of capitalist countries in the process of globalization. The role of developing countries is related to ensuring a balanced world economy. Globalization causes changes in world economic relations. Russia has taken an active position not only among developing but also developed countries. The article reveals that in the context of the US trade war with China and increased protectionism, developing countries have assumed the risks of losing capital and falling into a deeper and longer recession. Russia's position in economic globalization is linked to the place of BRICS in modern world order. Modern world order requires Russia to initiate the creation of new geopolitical communities, in addition to BRICS. To maintain Russia's stable position in the world economy, modern objective reality requires not only its participation in various geopolitical communities, but also their initiation.
\end{abstract}

\section{Introduction}

The relevance of the study of Russia's position in economic globalization is determined by the need to understand the real limit and opportunities for the development of the country as a whole. The whole as a generalized characteristic of the complex structure of a country reflects the degree of integration of its parts, self-sufficiency and autonomy, as well as the opposite of the environment.

In the context of globalization the opposite of countries manifests itself in their unity, connected by internal activity, and is characterized by a qualitative originality due to their inherent laws of functioning and development. The prerequisites for globalization are the world division of labour, world movement of capital and production resources, labour migration, standardization of economic, technological, institutional processes, convergence and fusion of cultures of different countries. As a result of globalization, the world acquires the property of a system - the preservation of purposeful integrity and identity to itself.

Understanding the process of economic globalization will help determine Russia's place in the modern world, evaluate it as a self-adapting system, and determine development opportunities.

\footnotetext{
*Correspondingauthor: walera712006@mail.ru
} 


\section{Materials}

The concept of globalization is associated with the essence of globalism. Globalism is an integral system of interrelated ideological, political, economic, and social measures aimed at establishing the dominance of certain socio-economic, political, ideological, religious doctrines on a global scale. On a global scale, globalization is laid down in the UN Sustainable Development Goals (SDGs).

The SDGs contain 17 global goals and 169 related tasks that determine the direction and order of actions for states to improve the well-being of the population and protect the planet. The country demonstrates a steady economic growth in terms of openness and integration into the world economy. Countries may experience lower medium-term production growth rates after the financial crisis, when globalization reaches a certain threshold.

Benefits and vulnerabilities accumulate in low-income countries [1]. In large emerging market economies, there is cross-dependency and cross-country heterogeneity [2].

In India, the domestic credit cycle is largely synchronized with the global financial cycle. In Indonesia, synchronization is indirect. In India, a higher exchange rate leads to a credit boom, which indicates financial risks. In Indonesia, the credit boom is due to the indirect impact of the global financial cycle through the real economy. The Reserve Bank of India adheres to an inflation targeting policy to reduce financial risks.

Sensitivity of the main global components of liquidity, international loan and bond flows to global factors has varied significantly over the past decade. Sensitivity to the US monetary policy increased immediately after the 2013 global financial crisis, and then returned to pre-crisis levels [3].

Duration of global financial cycles plays a definite role in the global financial system, which is determined by fluctuations in short-term capital flows, changes in monetary conditions in central economies, and combined movement of asset prices [4]. Globalization in the short and medium term is linked to financial development [5]. Economic globalization has an impact on national innovations. Globalization leads to an increase in the efficiency of innovations in countries with an average level of innovations among OECD countries [6].

Global trends and factors that cause an objective need to switch to an innovative type of fixed capital renewal determine the objective need to form attractive investment processes for updating the environment [7].

Competition of national innovative economies is a natural phenomenon in the context of globalization. Competition among the world's leading innovation-oriented countries is intense, but it does not lead to changes in the list of these countries. Russia actively and successfully participates in this competition [8]. The certainty of Russia's position in economic globalization will allow us to identify opportunities for removing existing contradictions.

\section{Methods}

To assess Russia's position in economic globalization, we apply descriptive statistics methods that include processing of empirical data, systematization, visual representation in the form of graphs and tables, their quantitative description by means of basic statistical indicators [9].

The use of cluster analysis is due to the fact that statistical methodologies rely on probabilistic understanding of causality and require justification of the connectivity of changes in the estimated indicators. Neural network analysis allows us to form neural networks that reflect patterns of changes in objects. 


\section{Results}

Empirical accumulation of information about the current position of Russia in economic globalization is mediated by the assessment of generalizing indicators of financial and economic activity of the following indicators: (1) rates of gain (RG) of GDP for 2014-2019 (base in national currency); export goods, free on board (FOB) cost (base in US dollars); consumer price index, \%; reserves minus gold (base in US dollars); (2) current and projected balance of payments (as a percentage of GDP), for 2014-2024, according to the International Monetary Fund (IMF).

The choice of the balance of payments and GDP, the value of export goods, and the consumer price index as a criterion for assessing Russia's position in economic globalization is due to the fact that global imbalances have significantly decreased after the global financial crisis. Debtor countries adjust their current account imbalances (deficits), while creditor countries increase their surpluses [10].

The analysis of the median values (Me) ofRG GDP, export goods, consumer price index, reserves minus gold for 2014-2019 has revealed a generalized order of modern world economic activity, which is based on the law of capitalism, the law of movement of the capitalist economy. The content of the law of capitalism is determined by the basic production relationship of capitalism between wage labour and capital as a process of production and appropriation of surplus value.

The dominant capitalist countries that define the modern form of globalism - Germany, the United Kingdom, the United States, and Japan, maintain low RG GDP and consumer price index. Developing countries such as Azerbaijan, Belarus, China, Egypt, Georgia, India, Indonesia, the Kyrgyz Republic, Mongolia, Nigeria, Russia, Rwanda, Tajikistan, the Philippines, etc., show high RG GDPand consumer price index.

The entry of the world economy into recession has caused a slowdown in globalization and, as a result, RG exportsfrom developed countries Switzerland, Australia, Canada, Germany, and Israel havebecome higher than RG exports from China. The shift in priorities has led to a change in the positions of the United Kingdom, the United States and Japan.

To preserve the concept of globalism in the context of the dominance of capitalist world economic activity, the United States has intensified the struggle for markets through a trade war with China and strengthening protectionist measures. Developing countries in the context of capitalist globalization are unable to exist on low RG GDPand debt capital.

Russia is close in terms of RG: (1) GDP - with Mexico, South Africa, Fiji, Qatar, Armenia, Colombia, Iceland, Paraguay; (2) exports of goods - Tajikistan, Papua New Guinea, Indonesia, Brazil, Jamaica, Kyrgyzstan, Saudi Arabia, Azerbaijan; (3) consumer price index - Gambia, Nepal, Kenya, Tajikistan, Mongolia, India, Papua New Guinea, Brazil, South Africa; (4) reserves minus gold - Papua New Guinea, Israel, Thailand, Canada, Albania, Iceland, Republic of Korea, South Africa, Costa Rica, Colombia, Serbia, Sierra Leone, USA, Brazil, Azerbaijan, Portugal.

Based on the proximity of Russia in terms of RG GDP, exports of goods, value of exports, consumer price index, reserves minus gold, Russia's position in economic globalization is associated with countries other than China, of the BRICS geopolitical community. China, being freer from the corresponding coalition, is able to independently take a certain position in economic globalization. Russia's stable position in economic globalization is determined by the role of India, Brazil and South Africa.

The analysis of the current and projected median values of the balance of payments (as a percentage of GDP) for 2014-2024 has revealed a favourable world order for Russia. Russia has actively joined the ranks of developed countries such as Singapore, Taiwan, Switzerland, Malta, the Netherlands, Ireland, Norway, Germany, Denmark, Luxembourg, South Korea, Japan, Hong Kong, and Sweden in terms of high value Me of the balance of 
payments (as a percentage of GDP). Brazil, India and South Africa fell into the negative zone. China is in the positive near-zero zone.

The aggressive behaviour of the US towards China is associated with negative values of the balance of payments (as a percentage of GDP), which are largely determined by the imbalance in trade relations. In order to avoid the negative impact of aggressive US behaviour on China, Russia needs to initiate the creation of new geopolitical communities, in addition to BRICS.

The use of cluster analysis has allowed us to single out a group of countries for the new Russian geopolitical community (table 1), and neural network analysis - options for achieving the maximum and minimum importance of Russia (table 2).

Table 1. The new Russian geopolitical community, the positive value Me of the balance of payments as a percentage of GDP, 2014-2024

\begin{tabular}{|c|c|c|}
\hline \multicolumn{2}{|c|}{ Cluster } & The square of the Euclidean distance \\
\hline Russia & Qatar & 12.867 \\
\cline { 2 - 3 } & Denmark & 29.390 \\
\cline { 2 - 3 } & Slovenia & 104.371 \\
\cline { 2 - 3 } & Azerbaijan & 438.101 \\
\cline { 2 - 3 } & Kiribati & 542.124 \\
\cline { 2 - 3 } & Singapore & 1589.312 \\
\cline { 2 - 3 } & Guyana & 4959.838 \\
\cline { 2 - 3 } & Macau & 9392.313 \\
\hline
\end{tabular}

Note:Hierarchical cluster analysis - the average distance between clusters, the square of the Euclidean distance.

Table 2. Neural network analysis of the importance of countries in the Russian geopolitical community, the positive value Me of the balance of payments as a percentage of GDP, 2014-2024

\begin{tabular}{|c|c|c|c|}
\hline Country & Importance, $\%$ & Country & Importance, $\%$ \\
\hline Lithuania & 100.0 & Croatia & 100.0 \\
\hline Finland & 87.1 & Guyana & 88.8 \\
\hline Afghanistan & 76.5 & Korea & 71.1 \\
\hline Slovenia & 72.4 & Hungary & 67.0 \\
\hline Singapore & 71.7 & Sweden & 65.8 \\
\hline Israel & 68.4 & China & 64.2 \\
\hline Belgium & 68.2 & Lithuania & 61.0 \\
\hline Ireland & 64.5 & Singapore & 60.0 \\
\hline Denmark & 63.5 & Malaysia & 59.4 \\
\hline Thailand & 63.3 & $\ldots$ & $\ldots$ \\
\hline United Arab Emirates & 62.7 & Slovenia & 28.5 \\
\hline Trinidad and Tobago & 55.1 & Italy & 27.4 \\
\hline Switzerland & 53.0 & Vietnam & 26.9 \\
\hline Nigeria & 52.4 & Kuwait & 25.3 \\
\hline Spain & 46.6 & Thailand & 25.0 \\
\hline Italy & 45.0 & Nigeria & 24.8 \\
\hline Papua New Guinea & 44.8 & Ecuador & 24.4 \\
\hline Russia & 44.8 & Saudi Arabia & 24.2 \\
\hline Korea & 42.5 & Norway & 24.0 \\
\hline Japan & 42.1 & Japan & 22.6 \\
\hline$\ldots$ & $\ldots$ & Denmark & 17.3 \\
\hline China & 9.3 & Russia & 10.9 \\
\hline
\end{tabular}

Note. Multilayer perception, batch training. 
Combining the results of achieving the maximum importance of Russia in the geopolitical community has allowed us to identify the main countries for the new Russian geopolitical community - Denmark, Singapore and Slovenia.

\section{Discussion}

In modern world order, capitalist countries dominate in the process of globalization maintaining low RG GDP and consumer price index. To maintain balance of the world economy, developing countries are forced to ensure high RGGDP and consumer price index. The slowdown in globalization has caused changes in the existing world economic relations. Exports rates of gainfrom developed countries Switzerland, Australia, Canada, Germany, Israel have become higher than exports rates of gainfrom China.

To preserve its dominant position in the global economy, the United States has intensified the struggle for markets through a trade war with China and strengthening protectionist measures. Under the new US foreign policy, developing countries have assumed the risks of losing capital and falling into a deeper and longer recession.

Russia's position in economic globalization is linked to the place of BRICS in modern world order and is determined by the role of India, Brazil, and South Africa. China is freer from BRICS and occupies a certain position in economic globalization on its own.

The current conditions of globalization have made it necessary for Russia to initiate the creation of new geopolitical communities, in addition to BRICS. Among the main countries for a new Russian geopolitical community are Denmark, Singapore and Slovenia.

\section{Conclusions}

The current position of Russia in economic globalization is determined by the objective reality formed by the law of movement of the capitalist economy. For the current structure of the Russian economy, the possibility of its existence is associated with the need to participate in various geopolitical communities.

Participation in geopolitical communities ensures the preservation of a certain position of Russia in economic globalization. Russia plays a significant role in BRICS. Strained trade relations between the United States and China require Russia to create a new geopolitical community.

\section{References}

1. B. Candelon, A. Carare, J.-B. Hasse and J. Lu, International Economics, 161, 139 (2020)

2. G. Olasehinde-Williams and M. Balcilar, Research in International Business and Finance, 53, 101228 (2020)

3. S. Avdjiev, L. Gambacorta, L. S. Goldberg and S. Schiaffi, Journal of International Economics, 125, 103324 (2020)

4. Y. Akdi, S. Varlik and M. H. Berument,Physica A: Statistical Mechanics and its Applications, 5491, 124331 (2020)

5. J. Guan, D. Kirikkaleli, A. Bibi and W. Zhang, Resources Policy, 66, 101641 (2020)

6. M. Zheng, G.-F. Feng, S. Feng and X. Yuan, Economic Modelling, 83, 65(2019) 
7. V.V. Smirnov, T.V. Talanova, A.N. Zakharova, G.S. Dulina, I.B. Getskina and N.V. Huraskina, Proceedings of the 32nd International Business Information Management Association Conference (IBIMA), 6949 (2018)

8. V.V. Smirnov, A.N. Zakharova, T.V. Talanova, A.G. Abramova, S.A. Petunova, I.B. Getskina and M.N. Yaklashkin, Proceedings of the 35th International Business Information Management Association Conference (IBIMA), 7741 (2020).

9. A.P. King and R.J. Eckersley, Statistics for Biomedical Engineers and Scientists, 1 (2019)

10. E. Alberola, A. Estrada and F. Viani,Journal of International Money and Finance, 107, 102206 (2020) 